\title{
GAMBARAN MOTIF DAN BELIEFS PADA JAMAAH ASMAUL HAQ RANGKAH KIDUL SIDOARJO
}

\author{
Desta Ranggi \\ Ika Herani \\ Sumi Lestari \\ Program Studi Psikologi \\ Fakultas Ilmu Sosial dan Ilmu Politik \\ Universitas Brawijaya Malang \\ Jalan Veteran Malang 65145, Telp. (0341) 551611, 575777
}

\begin{abstract}
The aim of this study was overview about the motive and beliefs of individual who are member of the Asmaul Haq. The method called "amalan" has aimed to always remember God. The essence of the concept Asmaul Haq is belief. Method of research is qualitative with phenomenological research model. Data collection techniques used observation, interview, and documentation. Data was analyzed by phenomenological Moustakas (1994). There are four subjects research was selected by snowball sampling technique, consist of two male subjects and female subjects aged 21-50 years. The results showed that the motive whose owned four subjects are same, such as wants to bring something close to the God, become people better than before. The source of drive is internal and external drive of subjects. While the beliefs of four subjects consistently shows that faith wholeheartedly against Asmaul Haq is a right way to the God. The beliefs of four subjects that every expectation blessed or is not blessed by God is the best thing. There is no doubting or lost of beliefs who they feel. Beliefs gives positive emotion and gratification to subjects in their life.
\end{abstract}

Keywords: motive, belief, “amalan”, asmaul haq, gratification

PSIKOISLAMIKA. Jurnal Psikologi Islam (JPI) copyright @ 2015 Pusat Penelitan dan Layanan Psikologi. Volume 12 Nomor 1 Tahun 2015

\section{PENDAHULUAN}

Seiring perkembangan zaman, semakin majunya teknologi dan informasi menempatkan manusia ketidakpuasan yang tidak berujung dan pada akhirnya memunculkan pikiran sekulermaterialistik, karena praktik pendidikan agama pada individu cenderung bersifat antrophosentris bukan bernilai transendental yang bersifat teosentris dan menyebabkan dehumanisasi. Ilmu pengetahuan dibuktikan berdasarkan pada ada atau tidaknya suatu hal. Hal tersebut mengakibatkan pemikiranpemikiran rasional empirik yang bertumpu pada kebenaran sensual atau kebenaran logik. Manusia mulai mengalami krisis dalam dirinya karena pergolakan antara rasional kehidupan dan hubungan transendental (Ibniyanto, 2010). Manusia merasakan berkurangnya hubungannya dengan Tuhan karena cenderung mengabaikan andil Tuhan. Manusia lebih mengutamakan realitas kehidupan yang masuk akal akan suatu harapan dan kepastian daripada meyakini adanya campur tangan Tuhan dalam setiap kejadian di kehidupannya.

Menurut Tamami (2011), manusia pada masa kini menjadi manusia modern yang menurut manusia modern, perbedaan ruh dan jasad hanya dalam logika, tidak dalam realitas. Dikutip dari Pelikan, berdasarkan pandangan Carl Jung, manusia modern adalah "The man who is aware of the immediate present". Artinya manusia modern telah kehilangan keyakinan-keyakinan religiusitas, keyakinan- 
keyakinan metafisis dan eskatologis yang diganti dengan pemikiran materialisme. Selain itu, dikutip dari Muthahari berdasarkan pernyataan Auguste Comte bahwa mereka yang sudah mencapai tingkat pemikiran positif, pada tahapan ini, manusia lepas dari pemikiran-pemikiran religius dan filsafat dan masih global. Manusia sudah memasuki dunia materialisme yang mana manusia melihat suatu hubungan karena adanya sebab dan akibat (Tamami, 2011).

Manusia dalam kehidupannya pada masa kini cenderung kurang meyakini akan pengaruh besar dari agama dan Tuhan. Agama hanya dijadikan sebagai identitas diri tanpa mengaplikasikan dan memahami setiap detail aturan dan perintah dari Tuhan. Manusia banyak melakukan perubahanperubahan yang tidak dilandasi oleh pegangan dan tujuan hidup seperti dalam agama Islam yaitu Al-Qur'an dan Hadist. Kurangnya religiusitas dalam diri manusia menyebabkan kualitas spiritual mereka juga mengalami penurunan. Pada dasarnya, agama adalah salah satu faktor yang dapat digunakan sebagai intervensi atau treatment dan pencegahan dari gangguan mental secara efektif. Hal tersebut disebabkan karena agama memiliki efek sikap positif dalam memaknai kehidupan karena didalamnya terdapat unsur keyakinan dan perilaku keagamaan seperti beribadah, mempercayai keberadaan Tuhan, dan memiliki sikap positif atas sebuah harapan (Marashian dan Esmail, 2012).

Berdasarkan hasil observasi, perwujudan akan kesadaran beragama banyak dilakukan oleh manusia beberapa kurun waktu terakhir. Dalam menyikapi krisis spiritual dan religiusitas, manusia mencoba mencari dan mengikuti setiap kegiatan ibadah atau menjadi anggota dari sebuah kelompok yang memiliki tujuan kepada Tuhan. Manusia terdorong untuk melakukan suatu perilaku dalam hal kebaikan dan kebenaran sehingga mendapatkan pengalaman keagamaan. Dibalik pencarian kegiatan keagamaan, manusia pada dasarnya memiliki tujuan tersendiri ketika mereka memilih salah satu kelompok atau pemimpin yang dijadikan sebagai panutan atau pembimbing menuju kebenaran akan Tuhan. Tujuan tersebut yang mendorong seseorang untuk mengambil keputusan dan berperilaku. Manusia mempunyai alasan dibalik perilaku yang dilakukan, khususnya dalam hal mengikuti suatu kegiatan dari kelompok keagamaan. Beberapa kemungkinan alasan adalah karena manusia dengan sungguh-sungguh ingin lebih mendekatkan diri pada Tuhan. Ada yang sekedar mengejar sesuatu dari kegiatan tersebut. Ada juga yang sekedar ikut tanpa mengetahui alasan dari perilaku mereka. Alasan-alasan atau dorongan yang menyebabkan manusia melakukan suatu tindakan, berbuat sesuatu, atau bersikap tertentu adalah motif. Motif memberi tujuan, batasan, dan arah akan tingkah laku kita (Sobur, 2003).

Ketika manusia telah memiliki motif untuk melakukan suatu tingkah laku untuk mencapai tujuan, maka muncullah belief di dalam dirinya sebagai penguat motif untuk menghasilkan tingkah laku demi mencapai tujuan. Belief pun erat kaitannya dengan religiusitas dan spiritualitas. Selain erat kaitannya dengan religiusitas dan spiritualitas, belief juga erat kaitannya dengan budaya dan psikologis karena hal tersebut terdapat hubungan timbal balik, yaitu elemen-elemen subyektif dari budaya adalah elemen psikologis, sehingga budaya banyak mempengaruhi proses psikologis seperti sikap, keyakinan, norma, opini, nilai, dan perilaku, serta persepsi masa depan (Bagherian, Rocca, Thorngate, dan Salehinezhad, 2011).

Berdasarkan hasil wawancara, setiap tingkah laku manusia yang dilandasi dengan belief, maka cenderung berhasil. Ada hubungan timbal balik antara motif dan belief, karena tanpa adanya motif dalam mencapai tujuan, maka manusia tidak akan merasa memiliki belief dalam dirinya. Begitu juga sebaliknya, jika hanya ada belief dalam diri tanpa tujuan, keyakinan seperti apa untuk meraih tujuan? Setelah tujuan tercapai atas motif dan belief dalam diri, maka akan timbul kebahagiaan dan kepuasan. Menurut Tamami (2011), belief manusia yang berkurang membuatnya bimbang dan pada akhirnya akan menimbulkan ketakutan. Mengutip dari Seligman, berdasarkan data survey secara konsisten menunjukkan bahwa orang-orang yang religius lebih bahagia dan lebih puas terhadap kehidupan daripada orang yang tidak religius (Rahmawati, 2013).

Pemilihan kegiatan ibadah sebagai upaya menyikapi krisis spiritual dan religiusitas yang berlandaskan motif tertentu, manusia mulai mencari tahu mengenai ajaran-ajaran Islam melalui orang lain, institusi, kelompok, dan sebagainya yang lebih paham dibandingkan dirinya sendiri di lingkungan sekitar atau bahkan sampai ke tempat lain. Memperhatikan setiap details ilmu dan nilai yang terkandung dalam setiap ibadah dan pendidikannya. Jika sejak dini manusia telah diajarkan mengenai siapa diri mereka, kepada siapa mereka harus tunduk, dan untuk apa mereka ada di dunia ini, maka kesadaran membangun pengalaman 
beragama akan mudah karena memahami setiap ajaran syariat Islam (Jalaluddin, 2012). Salah satu kelompok yang memiliki kegiatan ibadah dengan tujuan akan mengingat Tuhan dan lebih dekat dengan Tuhan adalah majelis Asmaul Haq.

Berdasarkan hal tersebut, peneliti tertarik dengan kelompok atau majelis Asmaul Haq sebagai setting penelitian karena beberapa alasan yang telah dijelaskan di atas dan mengkaji setiap motif yang ada pada manusia ketika mereka memutuskan untuk bergabung dalam majelis ini. Peneliti juga tertarik akan belief yang menjadi inti dari amalan Asmaul Haq yang berlandaskan visi dan misi, serta tujuan dari Asmaul Haq dalam mendekatkan diri pada Tuhan dan mencapai kedamaian, kebahagiaan, dan kebermaknaan hidup.

\section{KAJIAN PUSTAKA Motif}

Menurut Ahmadi (2009), motif adalah sesuatu yang ada pada diri manusia yang menggerakkan atau membangkitkan sehingga manusia itu berbuat sesuatu. Setiap motif yang ada pada tingkah laku manusia disebabkan oleh kebutuhan akan tujuan tersebut. Maksud dari kebutuhan tersebut adalah manusia yang kurang atau kekurangan akan sesuatu hal. Manusia berusaha sesegera mungkin untuk memenuhi kebutuhan tersebut. Kebutuhan dan motif tidak dapat diamati secara langsung. Motif dapat diketahui atau terinferensi dari perilaku, yaitu apa yang dikatakan dan apa yang diperbuat seseorang. Motif juga membantu seseorang untuk mengadakan prediksi mengenai perilaku. Selain mengamati tingkah laku tersebut, untuk mengetahui dan meyakini adanya motif dan kebutuhan adalah dengan menganalisis.

Berdasarkan penjelasan di atas mengenai hubungan kausal antara kebutuhan dan motif, Ahmadi (2009) membedakan motif atas:

\section{a. Biogenic Motive (Motif Biogenetis)}

Motif yang berasal dari kebutuhan biologis sebagai makhluk yang hidup. Motif ini terdapat dalam lingkungan internal, bukan di lingkungan eksternal karena motif ini berkembang dengan sendirinya dalam diri individu.

b. Sociogenic Motive (Motif Sosiogenetis)

Motif ini timbul dalam diri individu dalam hubungannya dengan lingkungan sosial. Motif ini timbul karena adanya interaksi dengan orang lain. Motif sosiogenetis ini tidak sepenuhnya timbul karena lingkungan tetapi adanya perpaduan antara individu dengan lingkungan.
Antara individu satu dan individu lain berbeda sehingga sifat dari motif sosiogenetis adalah subyektif.

c. Teogenetis Motive (Motif Teogenetis)

Motif ini timbul karena interaksi antara manusia dengan Tuhan, seperti yang terwujud dalam ibadahnya dan dalam kehidupan sehari-hari dimana seseorang berusaha merealisasikan norma-norma agamanya. Di samping itu, manusia memerlukan interaksi dengan Tuhan untuk menyadari akan tugasnya sebagai manusia yang berkeTuhanan di dalam masyarakat yang heterogen.

Belief

Latipun (2008) menjelaskan mengenai belief adalah keyakinan, pandangan, nilai, atau verbalisasi diri individu terhadap suatu peristiwa. Mengutip penjelasan Fishbein dan Ajzen, belief mengacu pada kemungkinan subyektif yang dimiliki seseorang tentang hubungan antara obyek belief dengan obyek nilai, konsep, dan atribut lain. Melalui berbagai pengalaman dengan lingkungan, individu membentuk berbagai macam belief tentang obyek, tingkah laku, dan kejadian. Selain itu, belief juga merupakan hasil dari observasi langsung maupun proses inferensial, sehingga individu dapat mempunyai belief tentang suatu tingkah laku tertentu (Emqi, 2013). Belief sebanyak mungkin membutuhkan konsistensi mengenai dunia ini dalam keyakinan individu (Baumeister dan Bushman, 2011).

Meyakini dan Meragukan (Believing versus Doubting). Jika ada belief (keyakinan) ada kemungkinan doubting (keraguan). Penelitian terbaru telah menyarankan bahwa keraguan atau ketidakyakinan terpisah dari pemahaman, tetapi secara tiba-tiba, keyakinan secara otomatis sejalan dengan pemahaman. Mengutip pernyataan Gilbert, Tafarodi, dan Malone mengenai artikel yang berjudul "You Can't Not Believe Everything You Read" (Baumeister dan Bushman, 2011) bahwa sesegera mungkin kita memahaminya, mempercayainya, kemudian dan kemungkinan mengambil langkah kedua dari mengubah pikiran.

Ketekunan Hati dalam Keyakinan (Belief Perseverance). Salah satu bentuk keyakinan adalah mereka rentan sekali terhadap perubahan. Hal ini benar karena jika salah dalam meyakini akan suatu hal sekali saja, maka akan kehilangan keyakinan untuk selamanya dan inilah yang disebut dengan keyakinan hati atau keteguhan iman. Jika ingin memahami sesuatu dengan benar, ini bagus untuk mengolah kebiasaan dari percobaan dari teori lawan 
ke teori apa saja yang kamu yakini (Baumeister dan Bushman, 2011).

Keyakinan dan Penanggulangan (Belief and Coping). Keyakinan membantu individu untuk memahami dunia di sekitar mereka. Hal ini terlihat jelas ketika individu memiliki pengalaman permasalahan yang serius, seperti ketidakberuntungan atau bencana. Coping adalah suatu keadaan umum bagaimana individu berusaha untuk menyetujui trauma dan kembali ke fungsi dengan efektif dalam kehidupan. Penelitian mengenai coping sangat penting karena bermanfaat dalam memahami belief. Efek dari trauma beberapa dekade terakhir adalah kejahatan seperti perampokan di apartement yang meninggalkan trauma fisik yang berat terhadap korban.

Keyakinan Religius (Religious Belief). Agama merupakan sebuah kategori yang sangat penting dari keyakinan. Ilmu pengetahuan secara umum tidak bisa mengatakan sesuatu mengenai keyakinan agama apakah benar atau salah. Tanpa memperhatikan dari obyektivitas kebenaran, bagaimanapun, psikologi dapat memberikan pencerahan mengapa orang menerima keyakinan agama sementara yang lain menolak keyakinan agama yang sama. Sepanjang sejarah, agama telah menjadi bagian dalam menjelaskan dunia, khususnya banyak hal yang tidak bisa dijelaskan dengan ilmu pengetahuan. Agama juga menjelaskan hal kecil seperti bagaimana anak bisa sakit. Agama juga memberikan keuntungan seperti dukungan sosial, sebuah rasa dari makna, tujuan, dan arah tujuan hidup seseorang, lingkungan, dan mengembangkan kebajikan seperti kejujuran dan integritas. Mengutip dari Pargament, Smith, McCullough, dan Poll bahwa keyakinan agama dapat membantu seseorang mengatasi stres (Baumeister dan Bushman, 2011).

Keyakinan Irrasional (Irrational Belief). Keyakinan irrasional adalah keyakinan atau sistem berpikir seseorang yang salah, tidak masuk akal, emosional, dan karena itu tidak produktif (Latipun, 2008). Keyakinan paranormal adalah sebaikbaiknya keyakinan adalah logis dan statistik yang kurang. Orang dengan keyakinan irrasional akan mengalami kecemasan berlebih dalam dirinya, tidak dapat menanggulangi dengan baik rasa sakitnya, terlihat depresi sepanjang waktu, dan memiliki penghargaan diri yang rendah (Baumeister dan Bushman, 2011).

\section{METODE}

Penelitian yang akan dilakukan menggunakan metode penelitian kualitatif. Model penelitian yang digunakan adalah fenomenologi. Alasan menggunakan model penelitian fenomenologi karena penelitian ini berusaha mencari dan memahami pengalamanpengalaman manusia yang alami yang terjadi secara langsung dan sadar yang dilakukan secara mendalam oleh peneliti terhadap suatu fenomena yang berpengaruh besar terhadap psikologis manusia ketika mereka berusaha untuk menjadi manusia yang lebih dekat dengan Tuhan. Mengutip dari Creswell, dalam disiplin ilmu-ilmu sosial model fenomenologi lebih sesuai dengan ilmu psikologi atau pendekatan psikologi yang memfokuskan pada arti dari pengalaman manusia walaupun ilmu sosiologi juga dapat menerapkan model penelitian fenomenologi dalam konteks kelompok atau komunal (Herdiansyah, 2010).

Teknik pemilihan sampel yang digunakan peneliti adalah non-random sampling atau non-probability sampling. Dalam non-probability sampling terdapat teknik yang sering digunakan yaitu teknik purposive sampling. Strategi dalam purposive sampling dalam penelitian ini adalah snowball sampling (Herdiansyah, 2010). Terdapat empat subyek dalam penelitian dan berikut beberapa kriteria subyek, yaitu:

1. Laki-laki dan perempuan dewasa dengan rentang usia 21 sampai dengan 50 tahun. Kriteria subyek ini dipertimbangkan berdasarkan usia rata-rata jamaah yang ada di Asmaul Haq Rangkah Kidul Sidoarjo.

2. Terdaftar sebagai jamaah Asmaul Haq dalam kurun waktu minimal 3 bulan untuk jamaah baru dan minimal 1 tahun untuk jamaah lama. Kriteria subyek ini dipertimbangkan berdasarkan seberapa lama waktu yang digunakan dalam mengamalkan amalan secara konsisten dalam menimbulkan belief dalam diri subyek. Latar belakang kehidupan subyek menjadi pertimbangan dalam menimbulkan belief juga.

3. Terlibat langsung dan aktif dalam kegiatan jamaah Asmaul Haq Rangkah Kidul, Sidoarjo. Kriteria subyek ini dipertimbangkan dalam mengetahui motif subyek bergabung menjadi jamaah Asmaul Haq.

Teknik pengumpulan data yang digunakan, pertama observasi, jenis observasi yang digunakan adalah observasi non partisipan. Kedua, wawancara, jenis wawancara yang digunakan adalah semi terstruktur. Ketiga, dokumentasi (Herdiansyah, 2010). 
Teknik analisis data menggunakan fenomenologi Moustakas (1994). Alasan penggunaan analisis data ini karena data hasil wawancara dipilah-pilah berdasarkan pernyataan asli subyek kemudian dibahasakan dengan bahasa peneliti sendiri, sehingga memberikan kemudahan kepada peneliti untuk memahami dan mengetahui motif dan keyakinan atau fenomena dari sudut pandang subyek.

\section{HASIL}

Berdasarkan penelitian yang telah dilakukan, memberikan hasil, bahwa:

Tabel 1. Hasil Penelitian

\begin{tabular}{|c|c|c|c|}
\hline \multirow{2}{*}{ Kriteria } & \multicolumn{3}{|c|}{ Subyek Penelitian } \\
\hline & C & W & $\mathbf{R}$ \\
\hline $\begin{array}{l}\text { Dorongan Internal } \\
\text { dan Eksternal }\end{array}$ & $\begin{array}{l}\text { Hal yang mendasari ikut } \\
\text { ijazahan Asmaul Haq } \\
\text { pertama kali adalah } \\
\text { ajakan dari temannya, } \\
\text { F (Dorongan eksternal) } \\
\text { ljazahan yang terakhir } \\
\text { kali dilakukan dengan } \\
\text { tujuan bahwa C memiliki } \\
\text { niat dan tekad yang bulat } \\
\text { untuk berubah menjadi } \\
\text { orang yang lebih baik } \\
\text { (Dorongan Internal) }\end{array}$ & $\begin{array}{l}\text { Latar belakang E W merasa mendapatkan } \\
\text { ikut ijazahan Asmaul hidayah dariAllah karena pada } \\
\text { Haq karena ada dasarnya W ingin berubah } \\
\text { anjuran dari F dan menjadi orang yang lebih } \\
\text { suaminya, I (Dorongan baik lagi. W berdo'a kepada } \\
\text { Eksternal). Allah agar ia dipertemukan, } \\
\text { Pada dasarnya E dikumpulkan dengan orang- } \\
\text { memang berinisiatif orang sholeh, orang-orangyang } \\
\text { untukijazahan karena beriman karena sebelumnya } \\
\text { ingin berubah menjadi W berdo'a meminta diberikan } \\
\text { lebih baik. E merasa kehidupan yang berkecukupan } \\
\text { bahwa iamendapatkan tetapihatinya tidakmerasakan } \\
\text { hidayah dari Allah ketenangan juga (Dorongan } \\
\text { sampai ia mengenal Internal). } \\
\text { Asmaul Haq. Alasan ketika mendengar do'a } \\
\text { internal yang kedua istighotsah yang berbunyi } \\
\text { dari dirinya adalah "sa'altu ka ya ghofar...... } \\
\text { keyakinan yang wa'atif kulubal'alamina....". } \\
\text { ditunjukkan dengan bersama PakR dan MasAinilah } \\
\text { suatu kebenaran dan W mengenal Asmaul Haq } \\
\text { ia diberi pengertian dan ikut ijazahan (Dorongan } \\
\text { y a ng se be nar - Eksternal) } \\
\text { benarnya (Dorongan } \\
\text { Internal). }\end{array}$ & $\begin{array}{l}\text { Pada dasarnya Remang } \\
\text { ingin berubah menjadi } \\
\text { perempuan yang lebih } \\
\text { baik dari sebelumnya } \\
\text { (Dorongan Internal), } \\
\text { sehingga ia diarahkan } \\
\text { suamiuntuk ikut ijazahan } \\
\text { Asmaul Haq (Dorongan } \\
\text { Eksternal). }\end{array}$ \\
\hline
\end{tabular}


Keyakinan (Konsep Keyakinan C terhadap E hanya meyakini Wmenganggap bahwa Asmaul Keyakinan R mengenai Asmaul Haq) konsepajaran Asmaul Haq dengansatukeyakinan Haq ini adalah sebuah jalan Asmaul Haq tidak adalah intidarikehidupan benar-benar bahwa menuju Allah, jalan yang diragukan karenaiabegitu ini adalah segala sesuatu ini adalah suatu jalan membimbingnya untuk selalu sangat yakin, $\mathrm{R}$ tidak yang dituju oleh manusia yang benar menuju dekat pada Allah. dapat mengungkapkan adalah Allah, mencari Allah karena Eselalu Sebelummengikuti ijazahan, bagaimana ia harus ridho Allah, mendapatkan ingat yang diajarkan W sudah merasa yakin dengan me ndeskripsikan kasih sayang Allah, dan di Asmaul Haq bahwa Asmaul Haq, dan setelah keyakinannya.

menjadi orang yang inti dari Asmaul mengamalkan amalan dan Keyakinannya tersebut dicintai oleh Allah. Haq sendiri adalah manfaat Asmaul Haq dan menumbuhkan prinsip Menurut $C$, yang utama keyakinan. itu terbukti membuat $W$ bahwa apapun yang dari Asmaul Haq adalah E sudah yakin bahwa semakin yakin dan mantap. W terjadi dalam hidupku yakin, keyakinan hati Allahakanmemberikan mendeskripsikan keyakinannya adalah kehendak Allah. manusia untuk yakin rezeki kepadanya tersebutbahwakeyakinannya Segala sesuatu yang ketika mengamalkan pada saat yang tumbuh dengan cepat terjadi padanya adalah manfaat dan do'a amalan tepat. Emenyerahkan karena ia menyadari sebuah atas ridho Allah, jika Asmaul Haq dan akan semuanya padaAllah, pengertian mengenai hakikat bukan karena ridho Allah, apa yang sudah Allah ia hanya perlu yakin manusia. maka semuanya tidak kehendaki. pada Allah. akan terjadi.

Menurut C, keyakinannya

dapat ditulis dengan kata

"yakin banget".

Segala sesuatu yang

terjadi dalam hidupnya

karena kehendak Allah,

$C$ hanya meyakini hal tersebut

Keraguan $\quad \mathrm{C}$ merasa tidak pernah Emenjelaskan bahwa $\mathrm{W}$ tidak pernah merasakan $\mathrm{R}$ tidak pernah merasa meragukan Asmaul Haq, keraguan yangia alami keraguan selama di Asmaul ragu sedikitpun pada baikmengenai kebenaran bukan karena amalan $\mathrm{Haq}$ karena dari awal Allah melalui Asmaul amalannya, ajarannya, Asmaul Haq dan mengenal Asmaul Haq, ia Haq. R menegaskan tujuan yang benar. sebagainya, Emerasa sudah yakin bahwa Asmaul bahwa jika sudah yakin Keraguan Chanya terbatas yakin dengan Asmaul Haq adalah sebuah jalan berarti kita harus yakin pada pikiran manusia saja, Haq tetapi terbentur untukmengubahnya menjadi selamanya pada Allah yaitu ketika mengambil karenapikiranmanusia orang yang lebih baik. W dan akan mengetahui manfaat Asmaul itu sendiri yang menegaskan bahwa ia yakin kebesaran Allah Haq seperti mengisi, akhirnya menjadikan dengan seyakin-yakinnya membuang gangguan, kebimbangan ketika dalam hati bahwa tidak ada memagari, karena hal menghadapi suatu keraguan terhadap Asmaul tersebut berhubungan masalah dalam Haq dan amalannya atau dengan metafisik hidup ajarannya karena mengetahui tujuan dari Asmaul Haq sudah jelas

K e h i l a n g a n C tidaksampaikehilangan E tidak memiliki W sempat merasakan $\mathrm{R}$ menjelaskan bahwa Keyakinan dan keyakinannya karena perasaan kehilangan keyakinannya menurun atau ia tidak pernah merasa Penanggulangannya ia selalu diingatkan keyakinan mengenai menipis karena W memiliki bahwa keyakinannya teman-teman jamaah Asmaul $\mathrm{Haq}$. masalah yang mana pada berkurang atau bahwa dalam hidup ini Selebihnya tidak ada saat itu juga $W$ tidak ingat menghilang karena segala sesuatunya atas pikiran kehilangan kepadaAllah, lupa berdzikir, menurut $\mathrm{R}$, jika sudah ridho Allah. C hanya keyakinan, putus asa, lupa berdo'a pada Allah, yakin harus yakin dan perlu memutarbalikkan dan meninggalkan lupa meminta pertolongan jika memang tidak diberi pikirannya yang negatif Asmaul Haq karena kegagalan menjadi pikiran yang positif pada Allah karena pikiran oleh Allah artinya Allah dan hatinya sudah dipenuhi memiliki rencana lain oleh masalah.

terhadap Allah

W juga menyatakan bahwa ia sempat melanggar larangan Asmaul Haq, yaitu mencuri sehingga amalannya menjadi batal. 


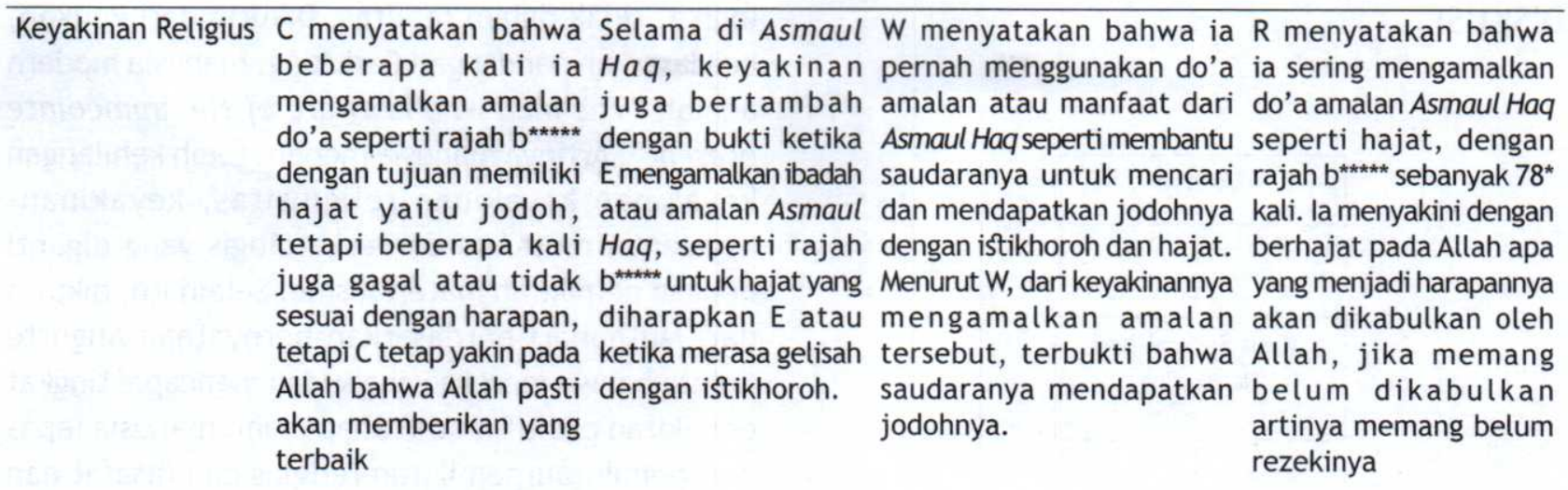

K e y a k i n a n Pada awalnya, C tidak Ejugameyakinibahwa W menjelaskan bahwa R meyakini bahwa Metafisik mempercayai dan barang seperti itu ia sempat mengalami manfaat dariAsmaulHaq meyakini tentang adanya memang ada karena pengalaman metafisiksecara memang salah satunya hal-hal yang berhubungan Allah menciptakan langsung terjadi pada dirinya. untuk melindungi diri dengan metafisik. Setelah makhluk tersebut. W meyakini bahwa barang- dari barang metafisik. membuktikan sendiri E pernah mengalami barang metafisik tersebut Selain itu, R juga pernah dibantu temannya $F$, kejadian metafisik ada di sekitarnya karena ia menyaksikan bahwa akhirnya $C$ yakin karena tetapi ia tidak menjelaskan bahwadiAsmaul burung peliharaannya merasakan sendiribahwa menceritakan kepada Haq diajarkan untuk selalu pernah disantet karena barang metafisiktersebut siapapun kecuali berdo'a dalam mengawali sempat dibedah tubuh masukdan menggerakkan orang terdekatnya sesuatu. burungnya terdapat paku tubuhnya karena kadang ada tembaga

orang yang tidak

mempercayainya.

Ketekunan Hati C berusaha istiqomah, E belajar secara Wmenyatakanbahwaiapemah Selama R yakin dan berdalam Keyakinan berusaha ajeg dan tidak $\mathrm{k}$ o $\mathrm{n} \mathrm{s}$ i st e $\mathrm{n}$ menjamak amalan karena positive thinking serta bolong-bolong dalam mengamalkanamalan, ada kesibukkan. Sedangkan menjaga sikapnya itulah sholat dan wiridnya menjalani apa yang untukmeningkatkan kekuatan salah satu cara untuk $\mathrm{C}$ berusaha mengingat ada di buku amalan, amalannya yaitu dengan menjagakeyakinannyadan Allah dalam hati sanubari, petunjuk-petunjuk, istiqomah selalumengamalkan membuktikan kebesaran dalam keadaan apapun dan cara-caranya. E setiap selesai sholat fardhu Allah. R menyebutkan karena dengan melakukan menyatakan bahwa dan tepat waktu. Jangan bahwa dengan yakin dan hal tersebut ia tetap dapat amalannya sering sampai menjamak atau terbukti secara otomatis menajda keyakinannya dijamak walaupun meninggalkan sholat dan akan percaya dan hal secara konsisten ia amalan Asmaul Haq. inilah yang membuatnya selalu mengamalkan selalu yakin

Gratifikasi C merasakan tenang, E merasa emosinya Ketenangan dalam hati yang Selama mengamalkan damai, dan tentram. C menjadi le bih dirasakan sangat luar biasa. amalan R menjadi lebih tidak merasa terbebani terkontrol. la merasa Kebahagiaan yang diukur tentram, lebih nyaman, dengan hal-hal dunia lebih tenang, karena bukan atas dasar materi lebih enak, menghadapi E membutuhkan tetapi lebih padakedamaian masalah tidak mudah ketenangan dalam secara lahir dan batin. gelisah. R lebih merasakan hidupnya ketenangan dan sifatnya yang berubah seperti keegoisan 


\section{DISKUSI}

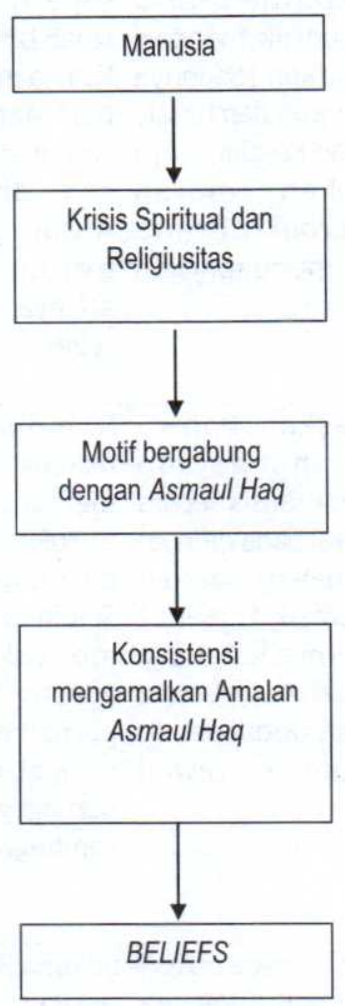

Berdasarkan bagan di atas, ada banyak hal di sekitar kita yang tidak pernah disadari mengenai bagaimana masing-masing individu mengalami krisis dalam kehidupannya. Krisis yang muncul ketika masa dewasa awal atau dewasa tengah salah satunya berupa krisis religiusitas dan spiritualitas. Terdapat beberapa hal yang menjadi penyebab individu mengalami krisis dalam dirinya, terlebih krisis yang dialami adalah krisis religiusitas dan spiritualitas, seperti pendidikan agama pada individu cenderung bersifat antrophosentris bukan bernilai transendental yang bersifat teosentris dan menyebabkan dehumanisasi. Ilmu pengetahuan dibuktikan berdasarkan pada ada atau tidaknya suatu hal. Hal tersebut mengakibatkan pemikiranpemikiran rasional empirik yang bertumpu pada kebenaran sensual atau kebenaran logik. Manusia mulai mengalami krisis dalam dirinya karena pergolakan antara rasional kehidupan dan hubungan transendental, misalnya individu cenderungkurang memahami apa tujuan ia diciptakan, apa tujuan hidupnya di dunia, dan sebagainya (Ibniyanto, 2010).

Menurut Tamami (2011), manusia pada masa kini menjadi manusia modern yang menurut manusia modern, perbedaan ruh dan jasad hanya dalam logika, tidak dalam realitas. Dikutip dari Pelikan, berdasarkan pandangan Carl Jung, manusia modern adalah "The man who is aware of the immediate present". Artinya manusia modern telah kehilangan keyakinan-keyakinan religiusitas, keyakinankeyakinan metafisis dan eskatologis yang diganti dengan pemikiran materialisme. Selain itu, dikutip dari Muthahari berdasarkan pernyataan Auguste Comte bahwa mereka yang sudah mencapai tingkat pemikiran positif, pada tahapan ini, manusia lepas dari pemikiran-pemikiran religius dan filsafat dan masih global. Manusia sudah memasuki dunia materialisme yang mana manusia melihat suatu hubungan karena adanya sebab dan akibat (Tamami, 2011).

Ada hal mendasar yang menarik individu untuk mengikuti ijazahan Asmaul Haq, yaitu kebutuhan individu dan manfaat Asmaul Haq. Apakah dorongan bergabung dari individu tersebut hanya sekedar ikut-ikutan, tertarik dengan manfaat Asmaul Haq, atau murni untuk mendekatkan diri pada Allah (Panggilan Tuhan), hal tersebut disebut dengan motif. Motif adalah sesuatu yang ada pada diri manusia yang menggerakkan atau membangkitkan sehingga manusia itu berbuat sesuatu (Ahmadi, 2009). Asmaul Haq memberikan jawaban dari setiap motif individu mengikuti ijazahan, yaitu dengan hikmah atau pengaruh yang diberikan selama mengamalkan amalan Asmaul Haq. Jika individu murni karena ingin mendekatkan dirinya kepada Tuhan, maka emosi positif akan didapatkan. Jika hanya sekedar ikut-ikutan atau tertarik dengan manfaatnya saja, kemungkinan emosi positif tersebut tidak sepenuhnya didapat karena Asmaul Haq mengajarkan untuk selalu mengingat Allah dalam keadaan apapun. Seperti pernyataan $\mathrm{F}$ mengenai hal yang menarik dari Asmaul Haq yang memberi dampak orang lain tertarik untuk bergabung, yaitu:

"Karena satu, Asmaul Haq sangat mudah diamalkan, karena selesai sholat cukup bertawassul dan mewiridkan ya berdzikir yang sudah ditentukan melalui Asmaul Haq, jadi mudah menjalankannya daripada amalan-amalan yang lain. Terus yang kedua hati dari pengamal-pengamal Asmaul Haq lebih tenang dalam menjalani hidup, tidak gampang gelisah dalam menghadapi masalah atau ujian-ujian atau cobaan" (transkrip wawancara F, 16 November 2014, baris 182-186)

"Ya ada, intinya dari jamaah kita ee... masuk bukan karena mereka punya suatu permasalahan tapi karena ingin agar bisa membuang gangguan dari jin, bisa mengobati orang, dan sebaginya 
ada yang seperti itu, ada juga yang sekedar ikutikutan, sekedar hadir itu saja, ada yang seperti itu, macem-macem, tapi hampir seluruhnya masuk ke Asmaul Haq karena ada problem atau permasalahan tadi" (transkrip wawancara F, 16 November 2014, baris 220-224)

Berdasarkan hal di atas, dapat disimpulkan bahwa jenis motif yang mewakili keempat subyek adalah motif teogenetis, yaitu motif yang timbul karena interaksi antar manusia dan Tuhan. Motif ini ada karena manusia ingin berinteraksi dengan Tuhan sebagai wujud kesadaran untuk mengenali dirinya dan tugasnya sebagai manusia yang berTuhan (Ahmadi, 2009).

Kesadaran manusia untuk mengenali dirinya dan tugasnya sebagai manusia merupakan bentuk pengalaman spiritualitas, karena spiritualitas memiliki ikatan yang lebih bersifat kerohanian dan kejiwaan (Tamami, 2011). Dari penjabaran di atas dapat diketahui gambaran motif dari masing-masing subyek terhadap Asmaul Haq. Jadi, pada dasarnya motif dari keempat subyek ingin berubah menjadi orang yang lebih baik lagi dari sebelumnya karena mereka memiliki latar belakang kehidupan yang jauh dari Tuhan. Subyek tidak terlalu mengutamakan manfaat yang ada pada Asmaul Haq, tetapi tidak dipungkiri juga ada kalanya manfaat Asmaul Haq dibutuhkan. Subyek hanya mencari ridho Allah, ketenangan, kedamaian, dalam hati. Dorongan bergabung dalam Asmaul Haq, bersumber dari internal dan eksternal subyek.

Konsep ajaran Asmaul Haq terletak pada tujuan dan do'a. Inti dari hasil setiap do'a amalan dan manfaat Asmaul Haq terletak pada beliefs masing-masing individu. Beliefs adalah suatu hal yang subyektif dan tidak dapat dicapai dengan akal manusia. Jika konsep ajaran dan amalan dari Asmaul Haq adalah belief secara penuh, maka keyakinan itu muncul sejak awal sebelum seseorang memulai mencapai harapannya dan setiap individu memiliki belief yang subyektif dan tingkat keyakinan yang berbeda tergantung dari keimanan masing-masing. Berawal dari keyakinan individu dan terbukti bahwa memang dengan belief yang penuh, maka individu semakin yakin dan percaya untuk mengamalkan setiap amalan dan manfaat Asmaul Haq dalam menolong diri sendiri dan orang lain.

"Ya keyakinan itu, yakin bahwa segala sesuatu atas ridho Allah. Kan sudah di setiap selesai sholat sudah ada do'a dari amalan Asmaul Haq yang dicari adalah ridho Allah. Jadi, kita harus mengharapkan ridho Allah. Kalau diridhoi ya yang terbaik tidak diridhoi ya yang terbaik. Harus bisa menanamkan kepasrahan dalam diri" (transkrip wawancara C, 28 September 2014, baris 229-232)

"Yaiya, kan kita sudah masuk Asmaul Haq dalam jalan lurus menuju Allah bagaimana lagi, apa yang kita tuju ya harus yakin toh? Terserah Allah, mungkin hari ini tidak dikasih rejeki, iyaa Allah belum sempat memberikan kepada kita. Allah kan belum memberikan kepada kita mungkin bisa diganti, atau apa itu. Itu dari keyakinan kita yang pasti Insyaallah permintaan kita tidak pernah istilahnya agak tertunda, ya tertunda itu hanya beberapa harilah. Karena kita selalu diajarkan untuk yakin dan yakin bahwa Allah akan menurutinya, bukan menuruti yang jelek-jelek" (transkrip wawancara E, 15 Oktober 2014, baris 186-192)

"Tapi di sini tujuan kita sebagai seorang manusia tidak lain adalah Allah. Benar begitu kan? Jadi di sini Asmaul Haq punya tujuan yang luar biasa yaitu untuk mengingat Allah dikala waktu berdiri, duduk, atau berbaring, atau mengingat Allah dikala sepi atau ramai" (transkrip wawancara W, 10 November 2014, baris 75-82)

"Ya awal-awalnya tidak seberapa yakin, tapi setelah ngamalin terus ada bukti kejadian ya dari situlah mulai tumbuh keyakinan" (transkrip wawancara R, 10 November 2014, baris 10-11)

Keempat subyek menggambarkan bagaimana keyakinan mereka terhadap diri mereka, Asmaul Haq, dan Tuhan, yaitu:

"Yakin bangettttt (sambil senyum dan menjawab dengan mantap) bangettttt!!! Ya kaya gitu tidak bisa diungkapkan dengan kata-kata. Karena deskripsi penjelasan dari keyakinan kan panjang" (transkrip wawancara C, 9 November 2014, baris 58-61)

“....Tidak terbersit ingin ini, ini, ini, yang ini membenarkan satu dengan lain yang wes, Hanya satu keyakinan yang betul-betul yakin bahwa inilah yang benar...." (transkrip wawancara E, 15 Oktober 2014, baris 139-143)

"Sangat yakin Mbak (tersenyum dan menjawab dengan mantap) yakinnya gini, kita manusia ini kan hakikat kita sebagai manusia ini kan diciptakan oleh Allah, dimuliakan, diberi tugas, dibebaskan memilih, dan bertanggungjawab.... Nah, dari situ saja sudah jelas bahwa manusia ini diciptakan di bumi ini tidak lain adalah untuk menjalankan perintah-perintah Allah, dari situ ditambah amalanamalan yang dari Asmaul Haq itu jadi seperti tuntunan gitu loh untuk menuju Allah, untuk lebih dekat menuju Allah" (transkrip wawancara W, 10 November 2014, baris 158-168) 
"Yakin!!! Yakin banget (menjawab dengan cepat dan semangat).... Ya kalau keyakinan memang susah ya untuk diungkapkan, karena adanya bukti tadi jadinya ya yakin saja karena ada bukti tadi. Pokoknya yakinlah" (transkrip wawancara R, 10 November 2014, baris 23-24; 45)

Berdasarkan hasil wawancara dengan $\mathrm{F}$ sebagai data sekunder, diperoleh data yang menjelaskan bahwa:

"Keyakinan ya kembali masuk dalam keimanan kita" (transkrip wawancara F, 16 November 2014, baris 258)

“.....Karena keyakinan kita letaknya di hati, meyakini di hati, disalurkan ke jiwa atau pikiran, dan dijalankan melalui tindakan. Kita sudah meyakini dari hati kita, dari keyakinan situ ditransfer ke pikiran atau jiwa, baru masuk ke tindakan.... Ya gitu, kalau urut-urutannya itu dibutuhkan yakin dulu kalau sudah yakin baru kita percaya" (transkrip wawancara F, 16 November 2014, baris 291-292; 321-323)

Baumeister dan Bushman (2011) menyatakan bahwa belief sebanyak mungkin membutuhkan konsistensi mengenai dunia ini dalam belief individu. Artinya setiap individu membutuhkan keyakinannya selalu ditambah dengan melakukan kegiatan ibadah dan sebagainya dan melakukan amalan-amalan yang berhubungan dengan belief sehingga semakin bertambah karena adanya konsistensi mengamalkan dari pengalaman-pengalaman fisik atau metafisik. Konsisten yang ditunjukkan subyek dapat dicontohkan dengan bentuk-bentuk ibadah kepada Allah dengan belief yang kuat untuk mencari ridho Allah. Hal tersebut seperti pernyataan $\mathrm{F}$ bahwa:

“Definisinya diambil dari kata ya'qin, yaitu suatu rasa dalam diri manusia bagaimana rasa itu dapat ditimbulkan melalui tindakan, bisa melaui suatu ucapan atau perkataan dan lain sebagainya. Jadi kalau masalah keyakinan kalau diambil secara globalnya, yaitu.... apa ya bahasa globalnya apa ya....??? sebelum kita membuktikan sesuatu ya? Apa yang akan kita jalani apa yang menjadi harapan dan impian kita sudah yakin, bahwa apa yang kita kehendaki pasti berhasil, karena kunci dari semua itu kan timbulnya dari keyakinan dalam menjalani suatu ibadah dan kehidupan.... Apalagi dalam hal ibadah dan suatu bentuk-bentuk perintah dari Allah SWT, semua itu kan harus diyakini bahwa senantiasa Allah selalu meridhoi, Allah selalu memberikan ridhoNya terhadap kita semua, bahwasanya segala bentuk ibadah kita semua kita meyakini Insyaallah Allah menerima, yang terpenting kan ibadah kita sesuai dengan apa yang sudah difirmankan dan disabdakan oleh Allah dan rasulNya" (transkrip wawancara F, 16 November 2014, baris 261-275)

Ada sumber daya yang jauh lebih besar dan kuat sebagai kekuatan dari amalan untuk mengabulkan permintaan subyek atas belief mereka, yaitu Tuhan. Mengutip pernyataan Jung, bahwa Tuhan adalah suatu kekuatan yang berpengaruh besar yang alami dan berpengaruhnya tidak dapat dibendung: Very personal nature and an irresistable influence, I call it God (Tamami, 2011). Begitu juga pendapat dari informan $\mathrm{F}$ bahwa:

“.... intinya Asmaul Haq ini kekuatannya dari ibadah, dari iman masing-masing. Tapi intinya kalau saya bilang kekuatan itu kan dari Allah ya, kita bisa kuat dari Allah, kita bisa menjadi lemah karena Allah.... semakin kuat keyakinan kita maka semakin kuat kekuatan yang ada di dalam diri kita dalam arti yang sudah diberikan Allah" (transkrip wawancara F, 16 November 2014, baris 249-255)

“....Asmaul Haq itu ilmu fadhillah, ilmu thoriqot. Yaitu ilmu pendekatan diri kepada Allah. Jika diamalkan akan membuahkan kekuatan (fadhillah) dari Allah secara otomatis" (transkrip wawancara S, 13 September 2014, baris 17-20)

Berdasarkan penjelasan di atas, dapat disimpulkan bahwa beliefs dari masing-masing subyek memiliki kesamaan dan perbedaan. Bentuk beliefs subyek bermacam-macam, ada yang yakin dengan metafisik, ibadah yang mereka lakukan, dan sebagainya. Kesamaannya terletak pada penggambaran mereka mengenai beliefs bahwa setiap subyek meyakini, yakin seyakin-yakinnya bahwa apa yang terjadi dalam kehidupan mereka atas dasar kehendak Allah, ridho Allah. Ketika mereka gagal atau tidak sesuai dengan harapan atas keinginan mereka berpikir positif bahwa itu belum menjadi rezeki atau yang terbaik untuk mereka. sehingga mereka pun tetap yakin pada Asmaul Haq dan Tuhan. Perbedaannya terletak pada pengalaman akan pembuktian dari amalan atau manfaat Asmaul Haq.

Tidak pernah ada keraguan dalam diri subyek terhadap Asmaul Haq hanya saja dua dari keempat subyek mengalami keraguan akan pikiran mereka sendiri bukan atas dasar ragu terhadap Asmaul Haq. Tidak sedikitpun juga beliefs keempat subyek hilang. Beliefs keempat subyek hanya sekedar berkurang atau batal karena konsistensi mengamalkan yang tidak tepat waktu. Coping mengatasi penipisan kekuatan Asmaul Haq atas belief dapat dilakukan dengan meningkatkan ibadah, baik ibadah fardhu atau sunnah, baik menaati aturan Asmaul Haq dan 
sebagainya. Selaras dengan penelitian yang dilakukan oleh Javanmard (2013) bahwa ada indikasi dari keyakinan beragama memberikan efek utama pada resiliensi. Dengan kata lain, keyakinan beragama melibatkan kekuatan utama dari resiliensi setiap orang agama sebagai sistem yang memiliki hubungan positif dengan kesejahteraan.

\section{KESIMPULAN}

Berdasarkan hasil analisis dan pembahasan pada bab sebelumnya, dapat ditarik kesimpulan bahwa:

1. Keempat subyek, yaitu C, E, W, dan R memiliki motif yang sama ketika akan bergabung dalam majelis Asmaul Haq, yaitu ingin lebih mendekatkan diri kepada Allah dan menjadi manusia yang lebih baik, sehingga motif keempat subyek mengarah pada teogenetis motive. Dorongan bergabung ke dalam majelis bersumber dari dorongan internal dan eksternal subyek.

2. Beliefs keempat subyek, yaitu C, E, W, dan R adalah:

a. Meyakini dengan sepenuh hati terhadap Asmaul Haq, baik amalan inti atau amalan do'a dan manfaatnya bahwa ini adalah salah satu jalan menuju Allah yang benar.

b. Keempat subyek tidak dapat mengungkapkan belief dengan kata-kata. Belief keempat subyek adalah segala sesuatu dalam kehidupan yang terjadi adalah kehendak Allah, sehingga dipasrahkan kepada Allah. Segala sesuatu yang terjadi adalah yang terbaik dari Allah.

c. Keraguan menimbulkan penipisan atau penurunan kekuatan belief. Keempat subyek tidak merasakan keraguan terhadap Asmaul Haq dan berpikir pernah kehilangan belief baik pada Asmaul Haq atau Tuhan, belief pada Tuhan tetap ada karena tujuan

\section{DAFTAR PUSTAKA}

Ahmadi, A. (2009). Psikologi sosial. Jakarta: PT. Rineka Cipta.

Bagherian, F., Rocca, C., Thorngate, W., dan Salehinezhad, M. A. (2011). Belief and expectations about the future of personal life and future of the world in a sample of Iranian and Canadian students. Journal of Social and Behavioral Sciences Volume 30 Page 602-607, yang utama adalah Tuhan.

d. Belief keempat subyek mengenai ibadah yang dilakukan adalah tetap ada, terlepas akan harapan yang diinginkan tidak diridhoi oleh Allah melalui amalan apapun. Keempat subyek meyakini bahwa apa yang Allah berikan itu adalah yang terbaik. Jika belum diberi atau diridhoi artinya adalah yang terbaik juga.

e. Konsistensi dalam mengamalkan amalan menguatkan belief keempat subyek dengan cara meningkatkan kualitas dan kuantitas beribadah, selalu berprasangka baik, dan berpikir positif.

f. Belief keempat subyek mengenai halhal metafisik adalah meyakini bahwa hal tersebut benar adanya dan subyek pernah mengalaminya. Subyek tidak merasa terganggu atau takut dengan hal metafisik tersebut.

\section{SARAN}

Berdasarkan hasil penelitian di atas, bagi penelitian selanjutnya yang yang mana akan menggunakan tema yang sama, sifat dari variabel penelitian yaitu motif dan belief bersifat subyektif sehingga setiap individu memiliki penggambaran masing-masing mengenai alasan apa yang mendorong individu bergabung dalam suatu kelompok keagamaan dan belief yang bagaimana selama individu berada dalam suatu kelompok. Oleh karena itu, untuk penelitian berikutnya, jika menggunakan variabel yang bersifat subyektif dan abstrak dalam penggambaran hasilnya lebih baiknya menggunakan pendekatan yang lebih dalam dengan subyek penelitian. Begitu juga dengan teknik pengambilan data, lebih baik menggunakan video sehingga dapat membantu ingatan untuk mengobservasi ekspresi subyek yang menunjang pernyataannya sehingga tidak hanya mengandalakan recording dari hasil wawancara.

Elsevier Ltd. Diakses pada tanggal 22 Maret 2014 pukul 17.14 WIB. http://ac.els-cdn.com/ S1877042811019410/1-s2.0-S1877042811019410main.pdf? tid=1918fcc8-cc4d-11e3-9af9-000 O0aacb35d\&acdnat $=1398411910 \quad 62608 \mathrm{f} 3 \mathrm{~d} 32$ 6129193b43612baa8116f6

Baumeister, R. F. dan Bushman, B. J. (2011). Social psychology and human nature. USA: Wadsworth Cengage Learning. 
Emqi, Z. H. (2013). Belief pada remaja penyalahguna alkohol. Jurnal Online Psikologi UMM Volume 01 No. 02, Tahun 2013 ISSN: 2301-8259. Diakses pada tanggal 19 Maret 2014 pukul 23.13 WIB. http://ejournal.umm.ac.id/index.php/jop/ article/view/1638/1734

Herdiansyah, H. (2010). Metodologi penelitian kualitatif untuk ilmu-ilmu sosial. Jakarta: Salemba Humanika.

Ibniyanto. (2010). Humanisme teosentris sebagai paradigma ideologi pendidikan islam (Studi buku ideologi pendidikan islam: paradigma humanisme teosentris, karya achmadi). Skripsi. Yogyakarta: UIN Sunan Kalijaga.

Jalaluddin. (2012). Psikologi agama. Jakarta: PT. RajaGrafindo Persada.

Javanmard, G. H. (2013). Religious belief and resilience in academic students. Journal of Social and Behavioral Sciences Volume 84 Page 744-748, Elsevier Ltd. Diakses pada tanggal 22 Maret 2014 pukul 14.58 WIB. http:// ac.els-cdn.com/S1877042813017126/1-s2.0S1877042813017126-main.pdf? tid=0b9c682ccc4e-11e3-9ea1-00000aacb361\&acdnat $=13$ 98412312 36a29ef8e94da64aef460ae05cb 8 fea3

Latipun. (2008). Psikologi konseling. Malang: UMM Press.

Marashian, F. dan Esmaili, E. (2012). Relationship between religious belief of students with mental health disorders among the students of Islamic azad university of ahvaz. Journal of Social and Behavioral Sciences Volume 46 Page 1831-1833, Elsevier Ltd. Diakses pada tanggal 22 Maret 2014 pukul 14.52 WIB. http:// ac.els-cdn.com/S1877042812015169/1-s2.0S1877042812015169-main.pdf? tid=735eedcecc4c-11e3-b083-00000aab0f02\&acdnat $=13$ 98411627_64d2e245328102b0ad8064e8415 $6 c 654$

Moustakas, C. (1994). Phenomenological research methods. California: Sage Publications.

Rahmawati, A. (2013). Makna kebahagiaan pada jamaah maiyah komunitas bangbangwetan surabaya. Skripsi. Malang: Psikologi Universitas Brawijaya.

Seligman, M. E. P. (2005). Authentic happiness. (diterjemahkan oleh: Rekha Trimaryoan). Jakarta: Pustakaraya.

Shoubari, M. (2005). Asmaul Haq: Jalan menuju Allah. Jombang: Yayasan Asma'ul Haq.

Sobur, A. (2003). Psikologi umum. Bandung: CV. Pustaka Setia.

Tamami, HAG. (2011). Psikologi tasawuf. Bandung: CV. Pustaka Setia 